\title{
Money Growth Variability and GNP
}

\author{
Michael T. Belongia
}

$\mathbf{R}$ that sharp fluctuations in the short-run growth rate of M1 since 1979 have reduced GNP growth, raised interest rates and generated expectations of higher future inflation. Mitton Friedman, for one, has concluded that variable money growth - by producing these conditions - was responsible for the shorter and more abrupt cycles in real income experienced over that period. 'Based on slightly different analyses, Bomhoff, and Mascaro and Meltzer also have concluded that variable money growth has tended to lower the level of output. ${ }^{2}$ Finally, a recent conference sponsored by The Cato Institute was devoted entirely to the adverse effects of variable money growth and methods by which money growth could be made more stable. ${ }^{3}$

Economic theory implies that variable money growth could lower the level of GNP by reducing its short-run growth rate, if this variability were associated with certain changes in money demand and velocty. This article reviews the theoretical case for such a link and provides empirical evidence on the existence of this relationship. The results support the notion that variable money growth - by increasing money demand and reducing velocity - has had significant negative effects on both the level and the growth rate of nominal GNP in recent years.

Michael T. Belongia is an economist at the Federal Reserve Bank of St. Louis. John $G$. Schulte provided research assistance.

${ }^{7}$ Friedman (1983).

${ }^{2}$ Bomhoff (1983); Mascaro and Meltzer (1983).

${ }^{3}$ See The Search for Stable Money (1983).

\section{THEOPETICAL PELATIONSIIPS}

The most common approach to constructing a link between variable money growth and CNP is based or: intermediate relationships involving money demand Athough the theory behind these relationships suggests that more variable money grouth will increase uncertainty about future economic conditions and increase the demand for money, the empirical evidence on this hypothesis has been mixed. "The discussion that follows, however, proceeds with a standard model of money demand and shows how more variable money growth - by increasing uncertainty - can be linked to a decline in the level of income and, possibly the long-run growth rate of GNP. Since the expected effects of variable money growth on inflation are assumed to be small, the conclusions that follow apply to real GNp as well."

\section{The Basie Tobin Model}

A money demand model derived by Tobin suggests that there is an explicit relationship between uncer-

\footnotetext{
${ }^{4}$ One statement of uncertainty's effect on money demand and interest rates is found in Friedman and Schwartz (1982), p. 39:

Another variable that is likely to be important empifically is the degree of economic stability expected to prevall in the future. Weatth holders ate likely to attach considerably more value to hqudity when they expect economic conditions to be unstable than wher they expect them to be highly stable. This variable is likely to be difficult to express quartitatively even though the direction of the change may be clear from qualitative infomation. For example, the otitbreak of war clearly produces expectations of instability, which is one reason war is often accompanied by a notable increase in real balances - that is, a notable decline in velocity.

${ }^{5}$ For one argument to support this assumption, see Friedman.
} 


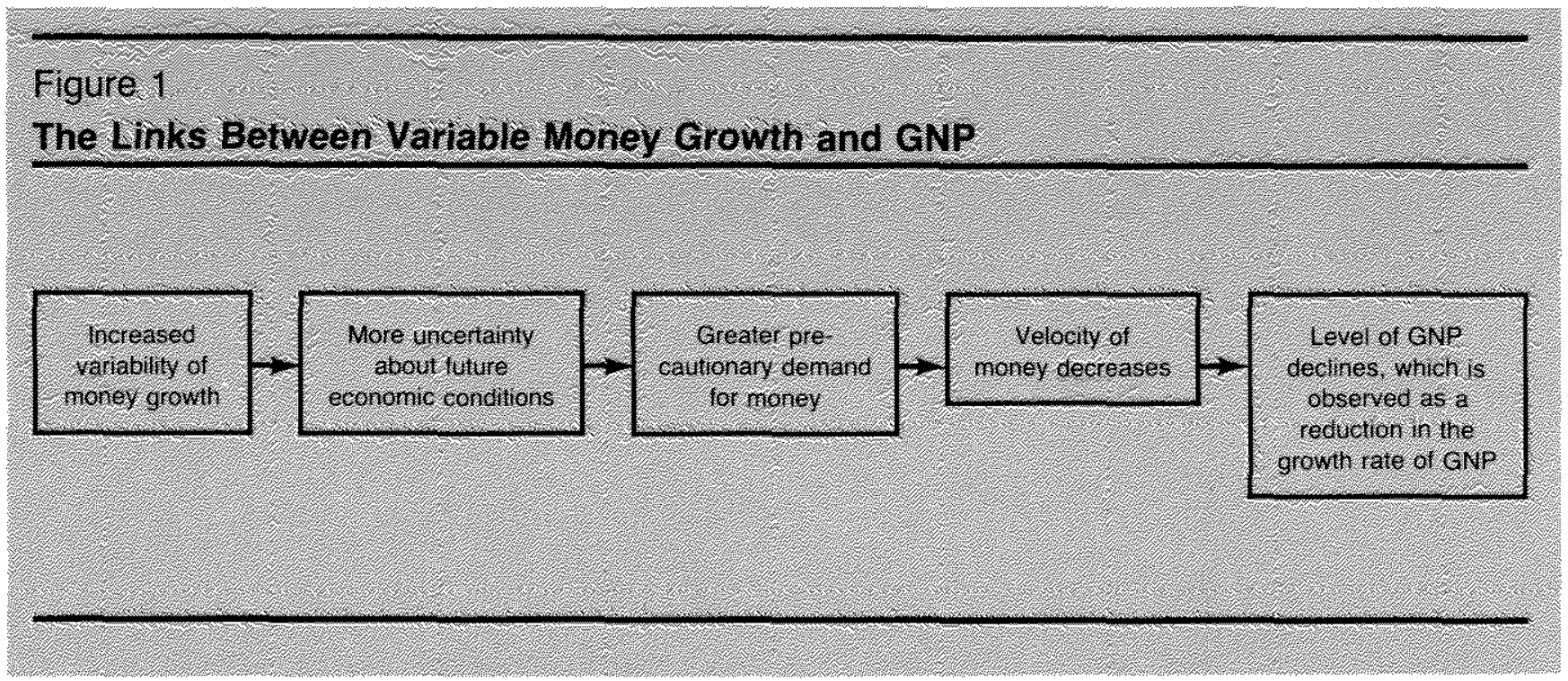

tainty about future values of interest rates and money demand ${ }^{6}$ In its most basic form, the model assumes that an individual can hold both money and government bonds in his portfolio. Moreover, if the yield on money is zero, both the expected retum of the portfolio and its variance depend on only the bond yield and the proportion of the total portfolio held in bonds. Therefore, in this simple world, an individual who seeks to maximize utility by holding some combination of cash balances and bonds in his portfolio faces a tradeoff between return and risk. That is to say, he can hold more bonds and increase the return on his portfolio only at the cost of increased risk: if the interest rate rises, the value of his bonds will fall. He can reduce risk, however, only by holding more cash balances, which reduces earings.

This model implies that risk and money demand are negatively related. "If more variable money growth in" creases uncertainty about future values of interest rates, greater money growth variability will result in an increase in money demand. This inverse relationship has been supported empirically in several studies." What remains to be seen, however, is whether this type of shift in money demand can be linked to a decrease in the level of GNP.

\footnotetext{
${ }^{6}$ Tobin (1958)

'Some economists disagree with this conclusion. For discussions of the theoretical indeterminacy of a sign relating uncertainty to money demand and supporting evidence, see Blejer (1979), Levi and Makin (1979), Smiriock (1982), Fieleke (1982), and Berson (1983).

${ }^{8}$ Klein (1977), Slovin and Sushka (1983), and Mascaro and Meltzer.
}

\section{Money Demand, Velocity and GNP}

The sequence of events depicted in figure 1 illustrates the first-round effects of greater money growth variability on uncertainty, money demand, velocity and GNP." Reading from the figure's left side, more variable money growth is hypothesized to cause greater uncertanty about future economic conditions. Increased uncertainty increases the precautionary demand for money. A higher level of money demand implies lower velocity (V). From the equation of exchange, MV $=Y$, lower velocity clearly implies a lower level for GNP (Y). Because GNP will shift to a lower level with some lag, this level shift will be observed as a temporary decline in the growth rate of GNP. After the adjustment process is complete, the growth of GNP should return to its long-run equilibrium path unless further changes in uncertainfy and risk premia tor other exogenous shocks set off another round of shifts in the levels of money demand and velocity.

\section{Theoretical Indeterminacy: Several Paths for GNP Are Possible}

Whether increased uncertainty about future money growth has any effect on GNP, however, is an empirical issue. Moreover, if increased uncertainty does have some effect on these variables, the nature of its effect could cause GNP to follow one of several different paths. For example, if the effect of greater uncertainty is a once-and-for-all shift in money demand, the level of

9This figure is adopted from a similar figure in Bomhoff, p. 98. 


\section{Table 1 \\ Estimates of a Reduced-Form GNP Equation Adding a Measure of Money Growth Variability}

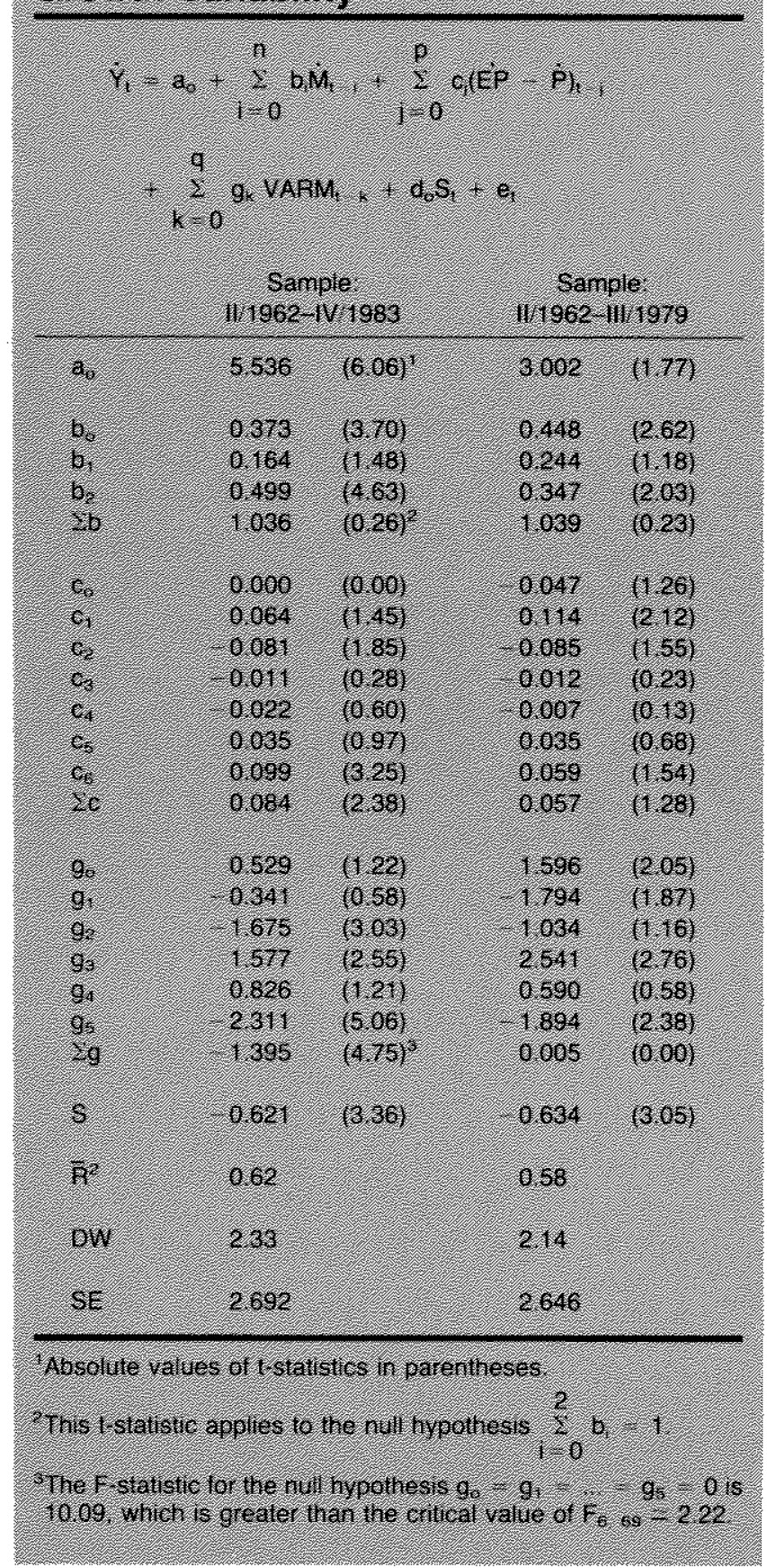

GNP will be permanently lower, but its growth rate eventually will retum to its former path. If the shift in money demand is transitory, however, there will be a short-run decline in the growth rate of GND, but netther the level nor the growth rate of income will be affected permanently. A third possibility is that greater uncertainty will alter investment decisions in a manner that also changes the economy's long-run capitallabor ratio; in this case, both the level and growth rate of GNP would be permanently lower, Finally, money growth variability may have no observable effect on uncertainty, money demand and velocity; in this event, neither the level nor the growth rate of GNP would be affected. Hypotheses concerning the impact of increased money grow h variability and these alternative paths for GNP are tested in the next section.

\section{SOME TESTS OF THE HVPOTHESES RELATING MONETARY VARIABILITI TO INCOME}

The effects of variable money growth on GNP can be tested by adding a measure of money growth vatiability to a basic reduced-form monetarist model of nominal GNP growth. The general reduced-form GNP equation to be estimated is shown at the top of table 1 . This equation expresses nominal GNP growth $(\dot{\gamma})$ as a function of the growth rate of $\mathrm{M} 1(\dot{\mathrm{M}})$, the relative price of energy $(\dot{E P}-\dot{P})$, the variability of money growth (VARM) and S, a variable that denotes periods of major strikes; the strike variable is deffned as the change in the quartely average of days lost due to strikes, deflated by the size of the civilian labor force. ${ }^{10}$

The measure of money growth variability chosen is the square root of a four-quater moving average of squared errors of money growth forecasts over the V/1950-IV/1983 sample period. ${ }^{11}$ The errors then were used to construct a measure of exror variability meant to represent changes in the risk or uncertainty faced by economic agents as the pattern of money growth changes. Intuitively, one might conclude that risk has

\footnotetext{
10The model chosen is discussed in Tatom (1981). The initial specification of the equation in table 1 also includes high-employment government expenditures as a right-hand-side variable. Pre-test statistics, however, indicated no significant marginal contribution to the model's explanatory power from this variable. This pre-test result is consistent with earlier studies that have found no long-run effect of government spending on GNP growth. See, for example, Andersen and Jordan (1968); Carison (1978); and Hafer (1982). For these reasons, the variable was omitted from the equation estmated in this paper.

${ }^{11}$ See Berson on the construction of a similar measure. The transformation is defined as:

$\left[\left(U \dot{M}_{t-1}^{2}+U \dot{M}_{t-2}^{2}+U \dot{M}_{13}^{2}+U \dot{M}_{-4}^{2}\right) \div 4\right]^{1 / 2}$,

where UM represents unanticipated money growth, i.e., the re siduals from an autoregressive model of money growth. Errors were generated by fitting a sixth-order autoregressive model to the growth rate of $\mathrm{M} 1$.
} 
Chart 1

\section{Estimates of Monetary Uncertainty Under Actual and Simulated M1 Growth}

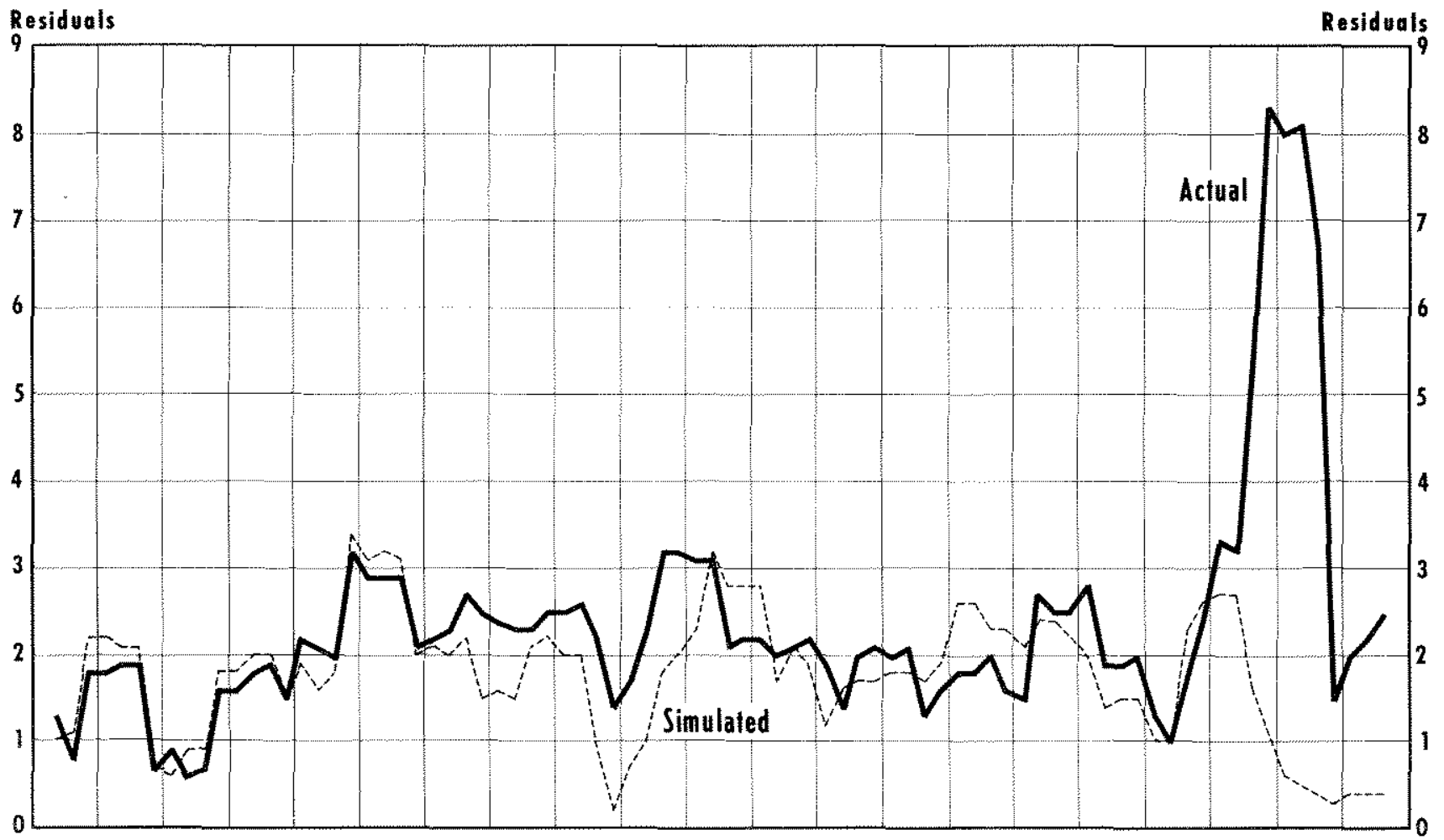

increased if forecasting errors begin to fall over an increasingly wider range. After all, the probability of making an incorrect economic decision increases with the probability of making a large forecasting error. This measure of money growth variability, represented by the solid red line in chant 1 , shows that forecast errors for $\mathrm{M} 1$ growth have been considerably more variable since 1979

\section{Pre-Test Estimation and Lag Length Selection}

The unknowns to be detemined in this equation prior to estimation are the lag lengths for money growth, relative energy prices and money growth rariability li.e, the $n, p$ and $q$ shown in table 1). These values were chosen following procedures discussed recently by Batten and Thomton."2 Pre-testing indi-

\footnotetext{
${ }^{12}$ Batten and Thomton (1983a, b) summarize an approach to the selection of lag length and polynomial degree based on the work $c^{f}$
}

cated the use of contemporaneots and two lagged quarterly values of the growth rate of M1, contemporaneous and six lags for the relative price of energy, and contemporaneous and five lags for the measure of money growth variability. ${ }^{13}$

The choice of five lags for the measure of money growth variability reflects the lagged responses of money demand, velocity and GNP suggested by theory and depicted in figure 1 . That is to sav, increased variability in money growth is expected to affect GNP only after some lag; economic agents require sufficient time both to discover the wider band of errors on money growth forecasts and to adjust their behavior accordingly. To test whether increased uncertainty

Geweke and Meese (1981): Mallows (1973); Schwartz (1978); Akaike (1969); and Pagano and Hartley (1981)

${ }^{13}$ The Pagano-Hartley -ratios, final prediction errors and Mallows test statistic all suggested these lag lengths. These lag lengths were fitted and chosen using ordinary distributed lag models without polynomiat smoothing 


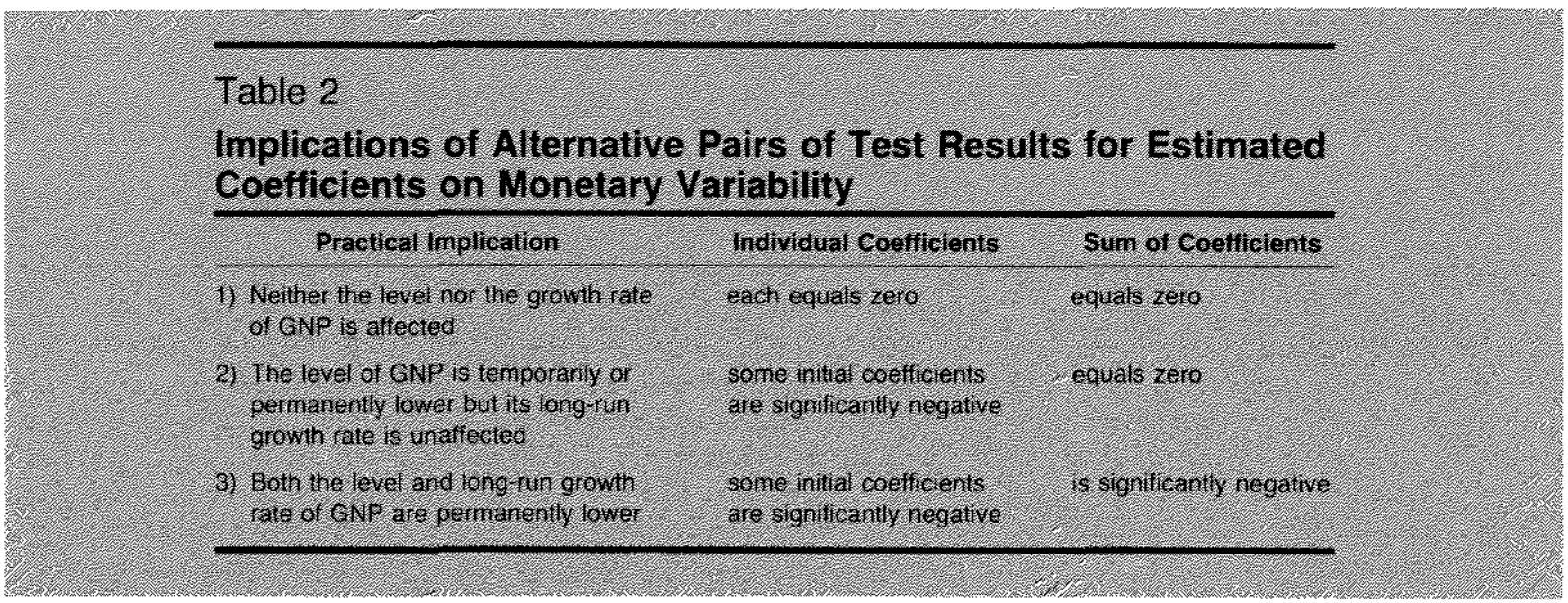

has an effect on the level of income, the relevant null hypothesis is $\mathrm{g}_{0}=\mathrm{g}_{\mathrm{g}}=\ldots=\mathrm{g}_{5}=0$, as shown in table 2 . Failure to reject this hypothesis would imply that money growth variability had no effect on GNP.

If one or more individual coefficients indicate a statistically significant negative relationship between GNP growth and money variability, the second issue of interest is whether this effect on the level and the growth rate is transitory of pemanent. In other words, it is important to know whether greater money growth variability causes a temporary or permanent reduction in the level and growth rate of GNP. This result can be determined by testing the null hypothesis that $\Sigma$

$g_{k}=0$. If this sum is not significantly different from zero but some individual coefficients are significantly negative, the results would imply a transitory decline in the growth rate of GNP and either a temporary or permanent reduction in its level. If this hypothesis also is rejected, however, it can be determined that both the level and growth rate of GNP are permanently lower. Implications of possible test results are summarized in table 2.

\section{TESTING THE IMPACT OF VARTABLE MONEY GROWTH}

The results of estimating the augmented GNP equation over the It/1962-IV/1983 sample period are given in the first column of table 1 . The results reject each of the null hypotheses discussed above: some initial individual coefficients for money gew th variability are significantly negative and their sum is significantly nega- tive. Within the context of the specified equation, these results indicate that greater short-tem variations in the rate of money growth tend to increase uncertainty and money demand; as a result, permanent reductions in both the level and the growth rate of nominal income are produced.

It also is important to note that the sum of the coefficients on money growth ${\underset{i}{\Sigma}=0}_{0_{i}}^{2} b_{i}$ is not significantly different from one after the addition of a direct measure of money growth variability. This shows that the one-to-one long-run correlation between the growth rates of money and nominal GNP remains, even after the effect of variable money growth is directly taken into account. ${ }^{14}$

The significance tests on the other variables included in the regression indicate that the strike variable has negative effects on income growth. Also, changes in the relative price of energy have exhibited some significant positive long-run effects on GNP growth. This latter result is not surprising; the impacts of short-run changes in relative energy prices are usually measured as changes in inflation. Thus, the relative energy price effect shows up in nominal GNP Ivia the price changel; and this explains the positive sum coefficient for relative eneray prices in this model.

\footnotetext{
${ }^{14}$ These results hold for a variety of variability measures, including a moving standard deviation of money growth, squared money growth rates and a multi-state Kalman filter estimate of the variance of errors associated with one-quarter-ahead forecasts of money growth. Unlike the criticisms of Allen with regard to uncertainty results for money demand these results tor a GNP equation appear to be robust with respect to the measurement of money growth variability. See Allen (1982).
} 


\section{Robustness}

As a check of the model's robustness, the equation in table 1 was re-estimated over a shorter II/1962-III/1979 sample period. This period was chosen for two reasons. First, the Federal Reserve changed its operating procedures in October 1979. Second, as shown in chart 1, there was a sharp increase in money growth variability after IV/1979. The results of re-estimating the GNP equation over the shorter sample period with new values for VARM are given in the second column of table $1 .^{15}$

The results for the shorter estimation period still indicate that variable money gowth temporarily lowers the growth rate of GNP. The long-run impacts on the level and growth rate of GNP, however, are no longer significantly different from zero. Apparently, the considerably lower variability of money growth that existed prior to 1980 did not produce any long-run impact on the growth of GNP. OF, viewed differently, even though variable money growth has a significantly negative effect on GNP in both periods, permanent reductions in its level and growth rate are found ony after 1980, when the variability of money growth tripled.

The effects of money growth and relative energy prices also follow lag patterns similar to those for the longer sample period. However, the long-run effect of relative energy prices is no longer significantly positive.

The only other apparent change from the full period estimation to this restricted one is a decline in the estimated growth rate of velocity (the model's constant term to 3.0 from 5.5. However, since the growth rate of velocity in this model is really $a_{0}+\sum_{k=0}^{5} g_{k}$, the implied velocity growth for the full-sample model is actually 4.14, which is not significantly different from $3.0 .{ }^{16} \mathrm{In}$ all other respects, the results for both models are qualitam tively similar and would seem to indicate that the addition of a money variability measure is robust with respect to choice of sample period.

\footnotetext{
${ }^{15}$ To reflect the tess volatile pattern of money growth that prevailed prior to 1980 , the autoregressive model of money growth used to generate values for the money variability measure was re. estimated. An AR(t) model was found to whiten the residuals for a model of money growth estimated over the pre-1980 sample.

${ }^{16}$ The F-statistic for $H_{0}: a_{0}+\sum_{k=0}^{5} g_{k}=3.0$ is 1.83 , less than the critical value for $F_{1,60}=4.00$.
}

\section{SOME IMPLICATIONS OF REDUCED MONETARY VARIABILITY FOR MONETAFY POLICY}

The estimates reported in table 1 support the hypothesized negative relationshp between variable money growth and GNP discussed elsewhere. ${ }^{17}$ However, the statistical measure of money growth variability is not expressed in units that have a clear economic meaning. Therefore, the results in table 1 may be difficult to interpret directly, especially for policy purposes. It may be useful to illustrate more intuitively why some economists are concemed about the poten" tial negative effects of money volatility. This is done below by using the equation in table 1 to repeat an experiment recently suggested by Fiedman. ${ }^{18}$

Friedman asked what the path of GNP would have been in recent years if the money stock had grown at the following rates over these intervals: 7.1 percent from III/1979 to III/1980; 6.1 percent from III/1980 to III/1981; and 5.1 percent from III/1981 to III/1982. ${ }^{19}$ The 6.1 percent three-year average growth ate described above is equal to its actual average over the same period. The plots of both actual M1 growth and Friedman's smoothed money path are shown in the upper panel of chart 2.

While maintaining the same average growth rates of money over four quarters, the Friedman scenario significantly reduces the large quarter-to-quarter variations in M1 growth that actually occurred over this period. This result is shown clearly by the sharp decline in money growth variability that is generated by these data; this new measure of monetary uncertainty is represented by the dashed line in chart 1 . Over the III/1979-III/1982 period, the more stable path of 11 growth would have produced - in terms of Friedman's analysis -- a longer but less severe recession in 1980 and, begiming around mid-1981, an expansion typical of the postwar period llasting about three years). The projected path of GNP under stable M1 growth is contrasted in the lower panel of chart 2 with the projected path of GNP under actual money growth.

The solid black line in the lower panel of chart 2 is the path of GNP produced by a simulation of the model reported in the second column of table 1 based on the

\footnotetext{
${ }^{17}$ For example, Friedman and Schwartz (1963b); Friedman; The Search tor Stable Money.

${ }^{18}$ Friedman.

${ }^{19}$ The experiment stops at this point because money growth acceler ated sharply and varied substantially over subsequent quarters.
} 


\section{Chart 2}

\section{GNP Growth and Alternative Money Growth Paths}

Actual and Smoothed Money Series

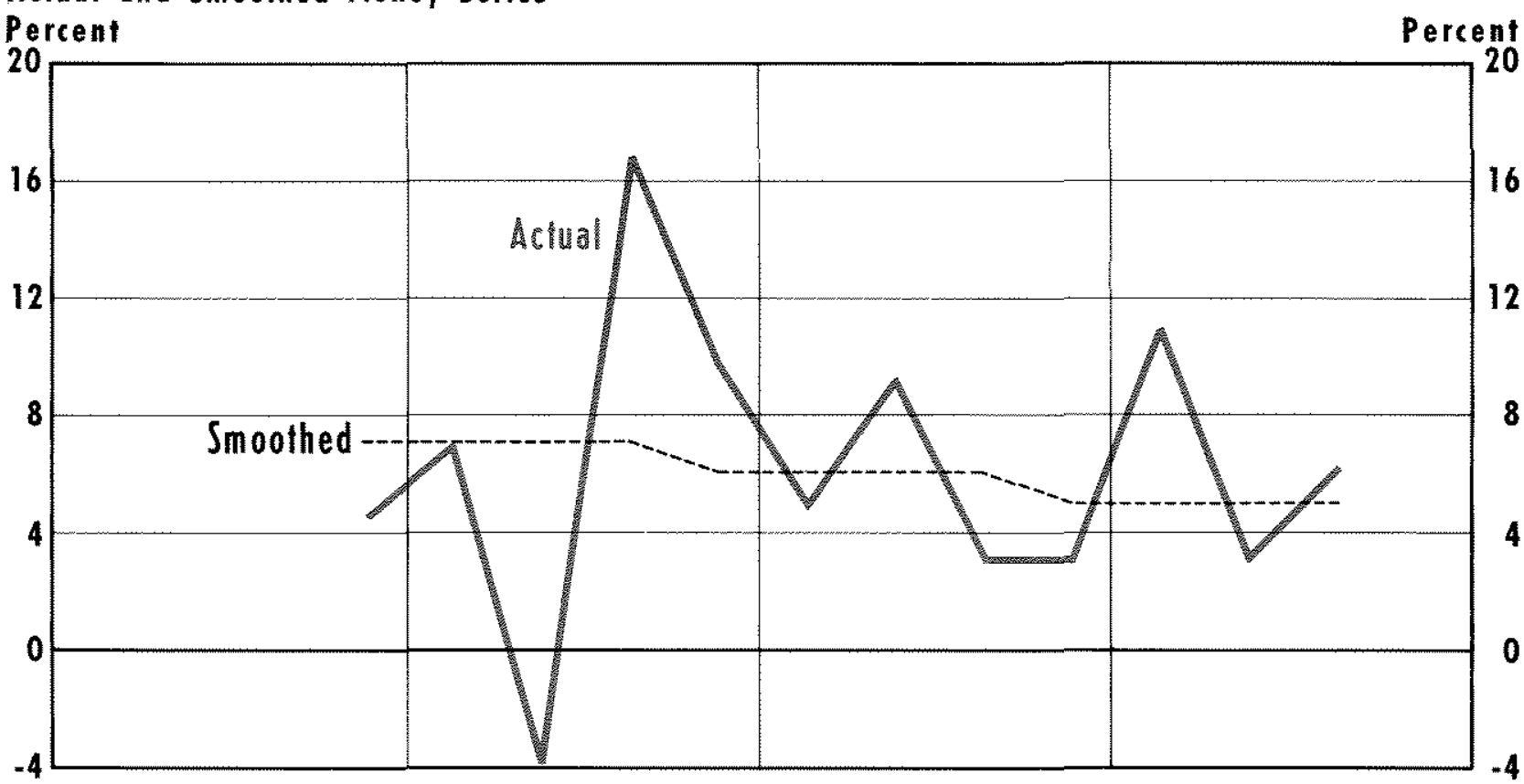

Actual and Smoothed Paths of GNP Growth

Percent

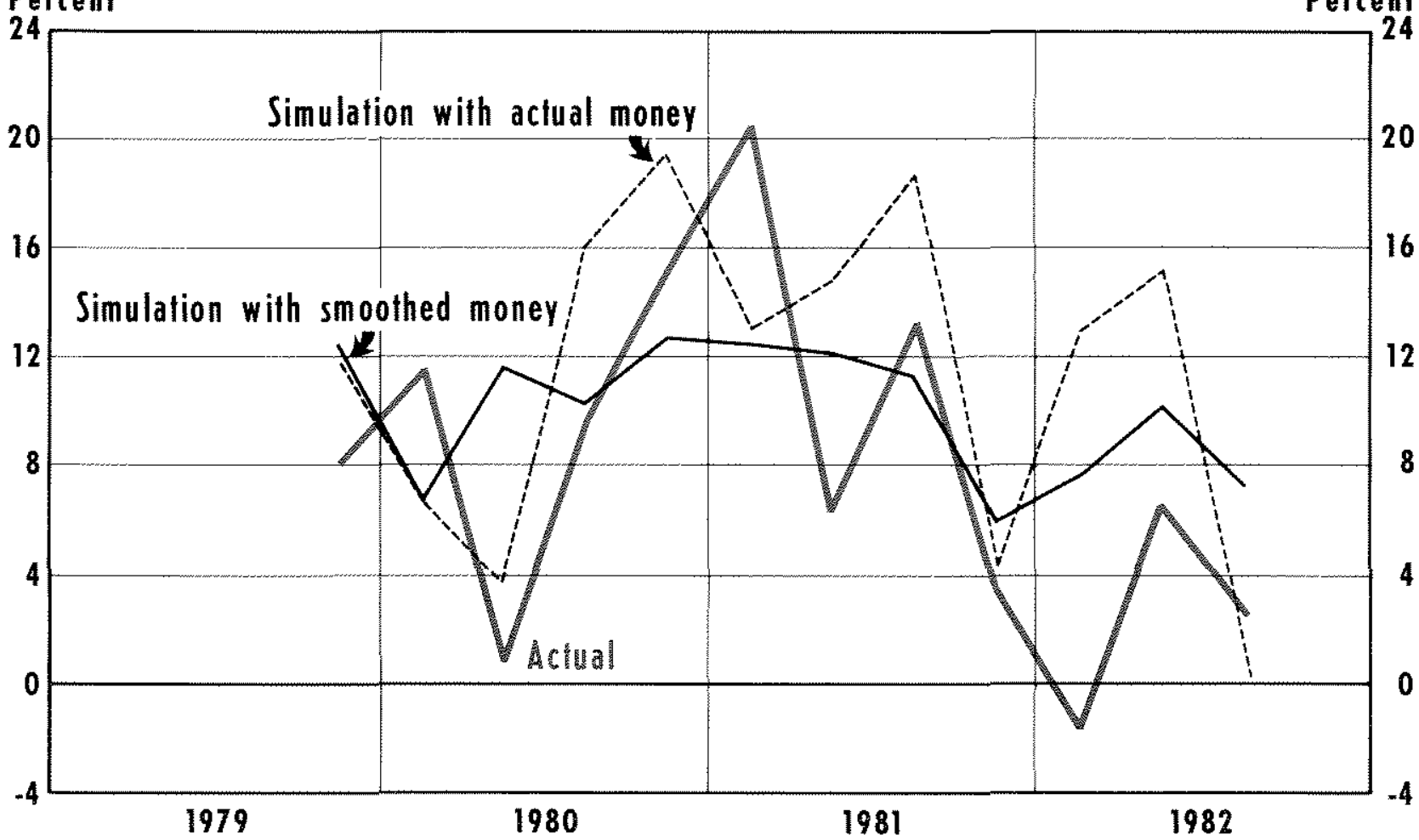


smoothed money growth figures listed above.20 The results are quite similar to Friedman's conjecture; moreover, they depict clearly what some economists clatm are the prospective benefits of more stable money growth. The simulated path of GNP growth under reduced quarter-to-quarter variation in M1 growth - shows higher average growth and much narrower variation than does actual GNP growth over this period. For example, actual GNP growth ranged between -2 and 20 percent; under more stable money growth, however, the simulated rates of growth in GNP vary between 7 and 12.5 percent. Moreover, while simulated GNP growth using actual money growth rates fell to zero in $11 / 1982$ and was 5 percent or below in three of the 12 quarters shown, the simulated path of GNP growth under less variable money growth fell below 7.5 percent on only one occasion. In summary, the contrasting resuls shown in chart 2 suggest that more stable money growth could promote a higher average level of GNP growth and reduce the range in which GNP growth fluctuates.

\section{CONCLUSHONS}

A number of recent studies have argued that variabiity in the quarter-to-quarter growth mate of money has increased money demand and, therefore, decreased the growth rate of GNP in the short run. This article investigates the link between variable money growth and GNP by adding a measure of money growth variability to a specific model of GNP.

The results suggest that increased quarter-toquarter variation in the growth rate of $M 1$ has some transitory negative effects both on the level and growth rate of nominal GNP; moreover, in more recent years, when the varation in money growth has increased nearly threefold, there is some evidence that the effects on the level and growth rate of GNP have been permanent reductions. If the effect of money variability on inflation is small, as is generally thought, these results imply a permanently lower level and, perhaps, smaller growth rate of real GNP.

\footnotetext{
${ }^{20}$ The dashed line was derived by using actual money growth rates and the errors from an autoregressive model fit to actual money data. These data provided the basis for projected GNP growth from 1//1979-HI/1982 under actual monetary conditions. Actual M1 data then were replaced with Friedman's figures for the Ill/1979-1I//1982 interval. The autoregressive model for money growth then was re-estimated over $\mathrm{V} / 1960-11 / 1982$ to generate a new error series and a new measure of money growth variability. The coefticient estimates reported in the second column of table 1 were used to re-simulate GNP growth over $\$ 979-82$ in an environment of more stable money growth. These simulated results are shown by the solid black line in chart 2
}

A simulation experiment based on these results illustrates the potential benefits of more stable money growth. Within the context of the model used, growth in nominal GNP would have been highes, on average, and more stable since 1979 if the quarter-to-quarter growth in M1 had been substantially less variable than it actually has been since then.

\section{PERERENCRS}

Akake, H. "Statistical Predictor Identification," Annals of the institute of Statistical Mathematics, vol. 21 (1969), pp. 203-17.

Allen, Stuart D. "Klein's Price Variability Terms in the U.S. Demand for Money," Journal of Money, Credit and Banking (November 1982), pp. 525-30.

Andersen, Leonal C., and Jerry L. Jordan. "Monetary and Fiscal Actions: A Test of their Relative Importance in Economic Stabilization," this Review (November 1968), pp. 11-24.

Batien, Dalias S., and Daniel L. Thornton. "Polynomial Distributed Lags and the Estimation of the St. Lovis Equation," this Review (April 1983a), pp. 13-25.

"Lag-Length Selection Criteria: Empirical Resulis from the St. Louis Equation, " Federal Reserve Bank of St. Louis Working Paper No. 83-008 (1983b).

Berson, David W. "Money Growth Volatility, Uncertainzy, and High Interest Rates," Federal Reserve Bank of Kansas City Economic Review (November 1983), pp. 23-38.

Blejer, M. I. "The Demand for Money and the Variability of the Rate of Inflation: Some Empirical Results, "International Economic Re. view (June 1979), pp. 545-49.

Bomhoff, Eduard J. Monetary Uncerfainty (Amsterdam: NorthHolland, 1983).

Carison, Keith $M$. "Does the St. Louis Equation Now Belleve in Fiscal Policy?" this Review (February 1978), pp. 13-19.

Evans, Paul. "Price-Level Instability and Output in the U.S.," Economic Inquiry (Aprit 1983), pp. 172-87.

Fey, R. A., and N. C. Jain. "Identification and Testing of Optimal Lag Structures and Causality in Economic Forecasting," in $O$. D. Anderson and M. R. Perryman, eds., Applied Time Series Analysis (Amsterdam: North Holland, 1982), pp. 65-73.

Fieleke, Norman S. "Fluctuations in Economic Activity and the Money Supply: An Overview." New England Economic Review (May/June 1982), pp. 5-14.

Friedman, Milton. "What Could Reasonably Have Been Expected From Monetarism: The United States," paper presented at the Mont Pelerin Society Meeting, Vancouver, British Columbia, August $29,1983$.

Friedman, Milton, and Anna J. Schwartz. A Monetary History of the United States, 1867 1960 (Princeton University Press, 1963a)

\footnotetext{
"Money and Business Cycles," suppiement to the Review of Economics and Statistics (February 1963b), pp. 32-64.

. Monetary Trends in the United States and the United Kingdom: Their Relation to Income. Prices and Interest Rates, 1867-1975 (University of Chicago Press, 1982).

Geweke, J., and R. Meese. "Estimating Regression Models of Finite But Unknown Order," International Economic Review (February 1981), pp. 55-70.

Hafer, R. W. "The Role of Fiscal Policy in the St. Louis Equation:" this Review (January 1982), pp. 17-22.
} 
Klein, Bentamin. "The Demand for Quality adjusted Cash Balances: Price Uncertainty in the U.S. Demand for Money Function," Journal of Political Economy (August 1977), pp. 691-715.

Levi, Maurice D., and John H. Makin. "Fisher, Phillips, Friedman and the Measured Impact of Inflation on Interest." Journal of Fjnance (March 1979), pp. 35-52.

Mallows, C. L. "Some Comments on $\mathrm{C}_{p}$," Technometrics (November 1973), pp. 661-75.

Mascaro, Angelo, and Allan $H$. Meltzer. "Long- and Short-Term Interest Rates in a Risky Wortd," Journal of Monetary Economics (November 1983), pp. 485-518.

Pagano, Marcello, and Michael J. Hartley. "On Fitting Distributed Lag Models Subject to Polynomial Restrictions," Journal of Econometrics (June 1981), pp. 171-98.
Schwartz, G. "Estimating the Dimension of a Model," Annats of Statistics, vol. 6 (March 1978), pp. 461-64.

Slovin, Myron B., and Marie Elizabeth Sushka. "Money, Interest Rates and Risk:" Journal of Monetary Economics (September 1983), pp. $475-82$

Smirlock, Michael. "Inflation Uncertainty and the Demand for Money," Economic Inquiry (July 1982), pp. 355-63.

Tatom, John A. "Energy Prices and Short-Run Economic Performance," this Review (January 1981), pp. 3-17.

"The Search for Stable Money." James A. Dorn, ed., The Cato Joumat (Spring 1983).

Tobin, James. "Liquidity Preference as Behaviof Toward Risk," The Review of Economic Studies (February 1958), pp. 65-86. 